AL IBTIDA: JURNAL PENDIDIKAN GURU MI (2020) Vol 7 (1) : 117-131

DOI: http://dx.doi.org/ 10.24235/al.ibtida.snj.v7i1.5127

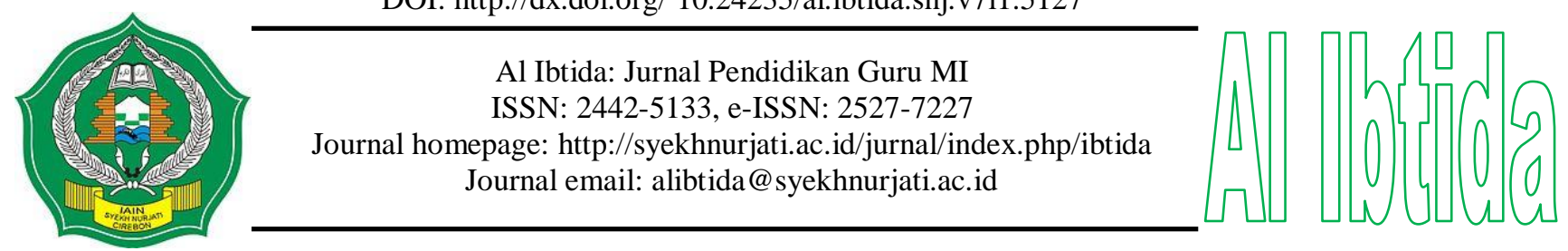

\title{
Developing Entrepreneurship Education Model in Improving the Skills of Recycling of Elementary School Students
}

\author{
Desak Made Darmawati* \\ *Department of Basic Education, Postgraduate Program, Universitas Negeri Jakarta, Indonesia \\ Email: dmdharmawati@uhamka.ac.id \\ Nadiroh** \\ **Department of Environmental Population Education, \\ Postgraduate Program, Universitas Negeri Jakarta, Indonesia \\ Email: nadirohdr@yahoo.com \\ Arita Marini*** \\ ***Department of Basic Education, Postgraduate Program, \\ Universitas Negeri Jakarta, Indonesia \\ Email: arita250268@yahoo.co.id
}

Received: February $03^{\text {th }}, 2020$. Accepted: April 04 ${ }^{\text {th }}$ 2020. Published: June $07^{\text {th }}, 2020$.

\begin{abstract}
This study was about developing an entrepreneurial education model in improving the recycling skills of elementary school students as well as to find out the improvement of aspects of knowledge, aspects of attitudes, and aspects of student skills through the entrepreneurship education model. This development research adopted the development design of Borg \& Gall. Model validation is done through expert judgment. Model trials were conducted in class V (five) in three elementary schools. Research data obtained through observation, questionnaires, and interviews. The results of this study indicate that the development of entrepreneurship education models in improving students' recycling crafts skills in primary schools based on the results of expert validation by $66.94 \%$ with a high category. The entrepreneurship education model developed can also increase the entrepreneurial knowledge aspect by $76.16 \%$, the attitude aspect by $79.84 \%$, and the entrepreneurial skills aspect by $82.64 \%$. This means that the increase in all three aspects is in the high category. Therefore, this entrepreneurship education model can be an alternative in developing entrepreneurship education in elementary schools.
\end{abstract}

Keywords: entrepreneurship education, recycling crafts, elementary school students.

\begin{abstract}
Abstrak
Penelitian ini bertujuan untuk mengembangkan model pendidikan kewirausahaan dalam meningkatkan keterampilan kerajinan recycling siswa sekolah dasar sekaligus untuk mengetahui peningkatan aspek pengetahuan, aspek sikap, dan aspek keterampilan siswa melalui model pendidikan kewirausahaan tersebut. Penelitian pengembangan ini mengadopsi desain pengembangan dari Borg \& Gall. Validasi model dilakukan melalui expert judgment. Uji coba model dilakukan di kelas V (lima) di tiga Sekolah Dasar. Data hasil penelitian diperoleh melalui observasi,
\end{abstract}


angket, dan wawancara. Hasil penelitian ini menunjukkan bahwa pengembangan model pendidikan kewirausahaan dalam meningkatkan keterampilan kerajinan recycling siswa di sekolah dasar berdasarkan hasil validasi ahli sebesar 66,94\% dengan kategori tinggi. Model pendidikan kewirausahaan yang dikembangkan juga dapat meningkatkan aspek pengetahuan kewirausahaan sebesar $76,16 \%$, aspek sikap sebesar 79,84\%, dan aspek keterampilan kewirausahaan sebesar 82,64\%. Artinya peningkatan ketiga aspek tersebut dalam kategori tinggi. Oleh karena itu, model pendidikan kewirausahaan ini dapat menjadi alternatif dalam mengembangkan pendidikan kewirausahaan di sekolah dasar.

Kata kunci: pendidikan kewirausahaan, kerajinan daur ulang, siswa sekolah dasar.

\section{INTRODUCTION}

Entrepreneurship education as part of the national education system function to develop the ability and character and civilization of the nation's dignity in the context of national life. The entrepreneurship education is aim to form the whole person (holistic) namely as a person who has the character, understanding and skills as an entrepreneur (Siwiyanti \& Uswatun, 2016). Tanan (2010) explained that in communities, ingrained false paradigm regarding entrepreneurship education, first, assume that if you want to include entrepreneurship education, and must create a new curriculum. This assumption is clearly erroneous. Because entrepreneurship education is not the form itself or independently (autonomy), but rather a unified (integrated), enrich and sharpen the existing curriculum. Putra \& Yuriandala (2010) in their research revealed that the development of student skills in elementary schools can be integrated with subjects related to environmentally friendly utilization of plastic waste into creative products that are useful for the nation.

Second, the assumption that teaches entrepreneurship education as well as to teach students to trade. This assumption is too narrow and clearly erroneous. Entrepreneurship education is not just shaping a person being an entrepreneur, but equip the person with mental entrepreneurship, whose scope is broader and complex. Third, the assumption that entrepreneurship education study after college or universities only. Assumption was wrong. The entrepreneurship education should begin from childhood, so that entrepreneurship is ingrained or become a cultural character of the child, not just a practical science (Usman, 2010). This is in line with research conducted by Robert (2019) that the introduction of entrepreneurship education bring positive effects on students if it starts from elementary school. The entrepreneurial spirit will be stronger and they already have a shadow or wishful, so that when you graduate can be independent by creating jobs themselves, without idle to others. Hassi (2016) stated that late childhood (11-12 years old) seems to be the adequate period in order to develop self-efficacy, a non-cognitive skill required to become an entrepreneur. However, content of entrepreneurship education should be consistent with 
students' needs and capability (Bahmani, Arasti, \& Hosseini, 2018); (Huber, Sloof, \& Van Praag, 2014).

The development of entrepreneurship education is directed at achieving economic growth that is supported by harmony between the availability of skilled manpower with the ability to create jobs or entrepreneurship, responding to the challenges of the labor requirements, and restructuring the school curriculum. The fact in the field show that current students is lack to be creative and less motivated in learning creative skills craft. This is because students overly increase the quality and the target in the learning process in the classroom. Besides that learning happens in the classroom, the teacher is not linking the material presented by everyday life, and students are given less opportunity from teachers to build their own and regain creative ideas (Shakir, 2017). Learning is now always the teacher guided the existing teaching material without applying to the state of the environment, so students are less friendly to the environment, the current situation and relate the needs of society, which has been established in primary schools. The results obtained merely numbers without producing any real creativity of the students' work.

Based on the above issues, one alternative solution in effort to repair the economy is with increase in the number of entrepreneurs need for introduction of entrepreneurship education in primary school, which aims to establish entrepreneurial character of children, that is to foster an attitude, skills, and knowledge a creative, optimistic self, brave, and skilled in every gesture. This is in line with whatever researched by Yohanna (2018); Wibowo \& Saptono (2018) that through skills, knowledge, and attitude that educators have can affect students. Besides that entrepreneurship education can be integrated into existing curriculum, practical learning in each subject at primary school (Azizi \& Mokhtari, 2018).

Some previous research related to entrepreneurship education model conducted by Agustina (2017) that through education model "market day" students have the ability to think logically, to have an attitude of confidence, cooperation and religious values, leadership, courage to bear the risk, independence, responsibility, and have a mental unyielding and able to be creative in practice entrepreneurial activity in the form of selling skills (market day). Cárcamo-Solís, Arroyo-López, Alvarez-Castañón \& García-López (2017) instilling entrepreneurial character through direct involvement of students in real entrepreneurial practice. Mulyani (2011) stated that instilling entrepreneurial values trough improvement in the curriculum, increasing the role of schools in preparing Entrepreneur, reform in organizing the learning process, and revamping the teacher himself. Dewi, Yani, \& Suhardini (2015) developing a model of etnopedagogic-based character and entrepreneurship education in 
elementary school. Sukardi, Ismail \& Suryanti (2014) developing a model of entrepreneurship based local skills. Putri (2018) use secondhand goods into economic value items. This study aims to develop an entrepreneurial education model in improving the recycling skills of elementary school students as well as to find out the improvement of aspects of knowledge, aspects of attitudes, and aspects of student skills through the entrepreneurship education model.

\section{METHODS}

This study adopts research and development ( $R$ \& D) which refers to Borg and Gall. Step-by-step development of entrepreneurial education model use the ten stages, namely 1) research and information gathering early; 2) planning learning; 3) model development; 4) validation and testing of the initial stage; 5) field trials; 6) revision of the product; 7) conduct field tests of the operational data were collected through observations and questionnaires; 8) improvements to the final product, based on suggestions in field trials; 9) to revise the main products, based on input and advice from the initial field test results; and 10) dissemination products.

The number of respondent of this research are 50 students from 3 elementary school in Jakarta. The model was developed and validated learning device by experts and practitioners. Entrepreneurship education model validation and test questions in this study conducted by seven validator comprising 3 validator experts and 4 practitioners are considered competent in the field of research that researchers discussed. Data collection technique in this research are questionnaires, observations, and interviews. This study uses two data analysis techniques, namely qualitative descriptive analysis techniques and descriptive statistics. This qualitative descriptive analysis technique is used to process observational data and interviews, while descriptive statistical analysis techniques are used to process data obtained through a questionnaire and data validation of experts and practitioners in the form of descriptive percentages.

\section{RESULTS AND DISCUSSION}

\section{Developing Steps of Entrepreneurship Education Models to Improve Skills of Recycling of Elementary School Students.}

As for the steps to develop entrepreneurship education models to improve elementary school students' recycling skills can be explained: First, preliminary study and information collection. In this step, researchers develop entrepreneurial education model with reference to the standards of competence and basic competence for developing subject matter, learning 
activities, and indicators of achievements to enhance the craft skills of elementary school students. The entrepreneurial education model was developed based on the results of preliminary observations made against school includes students, teachers, curriculum and resources to support. Based on the results of preliminary observations above is known to students are very pleased with the activity of recycling craft skills, it becomes its own motivation for students and teachers in the learning of entrepreneurship education. However, from the aspect of teacher, curriculum and another resources lack play a role in the collaborative implementation of student learning in entrepreneurship education activities and skills of weaving. Based on that, researchers are trying to develop entrepreneurship education model and skills of the craft in which all aspects can play a role in conducting entrepreneurial activity in the form of group work.

Second, planning development of entrepreneurship education model in recycling skills. As for the planning development of entrepreneurship education models in recycling skills is as follows:

Table 1. Development of Entrepreneurship Education Model in Recycling Skills

\begin{tabular}{|c|c|c|c|}
\hline No & Stages & Teacher Activity & Students Activities \\
\hline 1 & Preparation & $\begin{array}{l}\text { 1. Refers to the achievement of the goals } \\
\text { 2. Preparation tools and assessment } \\
\text { instruments which refers to the learning } \\
\text { objectives. } \\
\text { 3. Develop worksheet. } \\
\text { 4. Develop learning model. } \\
\text { 5. Teachers determine the group. }\end{array}$ & $\begin{array}{l}\text { 1. The formulation } \\
\text { contains objectives } \\
\text { on skills } \\
\text { 2. The perceived } \\
\text { needs of students } \\
\text { 3. Student make the } \\
\text { team group }\end{array}$ \\
\hline 2. & Plan & $\begin{array}{l}\text { 1. Organizing material systematically } \\
\text { arranged according to the syllabus, basic } \\
\text { competence, and indicators, divided into } \\
\text { two (2) entrepreneurial activity and craft } \\
\text { skills. } \\
\text { 2. Designing discipline students } \\
\text { 3. Planning instruments pre-test } \\
\text { 4. Programming is based on needs } \\
\text { 5. Identifying learning resources } \\
\text { 6. Observation instrument designing group } \\
\text { activities } \\
\text { 7. Making the learning plan, syllabus, } \\
\text { customized with the ability of students }\end{array}$ & $\begin{array}{l}\text { 1. Student make the } \\
\text { team group } \\
\text { 2. Students planning } \\
\text { tools and material } \\
\text { skills } \\
\text { 3. Students prepare } \\
\text { the tools needed }\end{array}$ \\
\hline 3 & $\begin{array}{l}\text { Organizing } \\
\text { the material }\end{array}$ & $\begin{array}{l}\text { 1. Creating a fun learning environment. } \\
\text { 2. Teachers determine instructional model } \\
\text { 3. Teachers condition students to prepare } \\
\text { tools and materials entrepreneurial activity } \\
\text { 4. Provide practical guidance skills } \\
\text { weave with plastic recycle } \\
\text { 5. Teachers condition for the practice of }\end{array}$ & $\begin{array}{l}\text { 1. Students prepare } \\
\text { tools and materials } \\
\text { in groups } \\
\text { 2. Students form } \\
\text { groups. }\end{array}$ \\
\hline
\end{tabular}




\begin{tabular}{|c|c|c|c|}
\hline \multicolumn{4}{|c|}{ entrepreneurship } \\
\hline 4 & $\begin{array}{l}\text { Learning } \\
\text { implementat } \\
\text { ion }\end{array}$ & $\begin{array}{l}\text { 1. Teachers read the rules } \\
\text { 2. Teacher gives initial test (Pre-test) } \\
\text { 3. The introduction of the material concept } \\
\text { of entrepreneurship and skills } \\
\text { 4. A description of how the practice of using } \\
\text { the tool and the plastic of } \\
\text { 5. Implementation of entrepreneurial } \\
\text { practice is participatory practice. } \\
\text { 6. Rolle learning model in the form of play } \\
\text { 7. Assist students in entrepreneurial practice. } \\
\text { 8. Teachers collaborate with teachers the } \\
\text { skills and artistry to make observations } \\
\text { observation of the child in the practice of } \\
\text { entrepreneurship }\end{array}$ & $\begin{array}{l}\text { 1. students listened } \\
\text { 2. Students carry out } \\
\text { pretest } \\
\text { 3. Students sit in } \\
\text { groups } \\
\text { 4. Students are ready } \\
\text { tools and materials } \\
\text { 5. Students listening } \\
\text { to teacher statement } \\
\text { 6. students practice } \\
\text { 7. Students practice } \\
\text { with repetition } \\
\text { 8. Team work. } \\
\text { 9. Self- } \\
\text { entrepreneurship } \\
\text { and skills } \\
\text { development }\end{array}$ \\
\hline 5 & Assessment & $\begin{array}{l}\text { 1. Evaluation Results } \\
\text { 2. Assessment using a pre-test and post-test, } \\
\text { 3. Instruments sheet performance } \\
\text { assessment (performance). } \\
\text { 4. Assessment Cooperation group } \\
\text { 5. Assessment of the results of creative skills } \\
\text { of participants in the group plastic } \\
\text { webbing. }\end{array}$ & $\begin{array}{l}\text { 1. characteristics of } \\
\text { students } \\
\text { 2. Skilled } \\
\text { 3. Active } \\
\text { 4. please } \\
\text { 5. Repetition }\end{array}$ \\
\hline
\end{tabular}

Third, develop primary form of product. The primary product that developed in this study is the form of a book entitled "Entrepreneurship Education \& Skills in grade v elementary school" with table of content: CHAPTER I. Entrepreneurship education and Skills; CHAPTER II. Entrepreneurship \& Creative (Life-skill); CHAPTER III. Entrepreneurship in Personal Development; CHAPTER IV. Types of Business; CHAPTER V. Entrepreneurship \& Weaving Craft; CHAPTER VI Values of Entrepreneurship Education; CHAPTER VII. Characteristics of Entrepreneurship; CHAPTER VIII. Making Batik Crafts; CHAPTER IX Creative Industrial Business and Utilization of Natural Resources ", CHAPTER X. Trade". The writing of this book is based on competency standards and basic competencies of entrepreneurship, and entrepreneurial characteristics, supplemented by competency tests, group assignments, and practice skills, student self-development, and marketing day.

Analysis of the product results developed in accordance with the theory and field results, so as to produce a textbook, "Entrepreneurship Education \& Skills". The product of this book is then tested by experts (product design expert test). Testing by these experts to prove the significance or worthiness of the book being developed. Validation testing by 
experts and practitioners in implementing the components of entrepreneurship education through creative industry skills in the form of teaching textbooks of creative skills weaving in groups.

For this reason, researchers try to develop entrepreneurship education learning models as models that contain creative craft skills weaving plastic bags with used plastic raw materials. Where entrepreneurship education subjects with skill content have never existed in elementary schools. Basically, entrepreneurship education is part of the creative and innovative skills that are instilled from an early age to college, with the aim of fostering the entrepreneurial spirit of students growing up, skilled and independent. Entrepreneurship education is not synonymous with selling or trading, but familiarize children to get accustomed to be skilled at everything.

Fourth, Validation and Testing Product Early Stage. Entrepreneurship education model validation and test product in this study conducted by seven validator comprising 3 validator experts and 4 practitioners are considered competent in the field of research that researchers discussed. The results of the validation of experts and practitioners states that the product developed is feasible for use. But there are some things that need to be revised, for example Language selection is not appropriate for elementary school students, Language rules are too high for the level of primary school student readers, the use of pictures and interesting illustrations need to be added, and the message delivered must be adjusted to the needs of school students basic. After subsequent validation phase models tested to determine the effectiveness of the model and the instrument. Experiments conducted on small groups and test expanded on a large group.

Fifth, the results of testing entrepreneurship education model. The results of product tests conducted by 3 validators obtained an average score of 60, where the ideal score is 90 . For that, to measure the results of the assessment of the 3 expert validators used the formula:

$$
A P=\frac{\text { skor aktual }}{\text { skor ideal }} \times 100 \%, A P=\frac{60}{90} \times 100 \%, \quad A P=67 \%
$$

Based on the scores obtained indicate that the assessment of 3 expert validators of the products developed is classified as high category, because it is at an interval of $61 \%$ to $80 \%$. Although the product developed is included in the high category, it still needs to be refined according to the advice of expert validators. As for what needs to be improved, the discussion of theory must be simplified according to the age of elementary school children and it is necessary to add illustrations to the pictures to make it more interesting and practice examples of handicraft skills of elementary school students. 
Sixth, entrepreneurship education model product revision. After the validation and testing of the model of entrepreneurship education in mind there are many revisions on the steps of the writing of entrepreneurship education products that have been developed. The initial design created does not change, just that there needs to be additional more detailed explanation on the syntax of entrepreneurship education. Emphasis language in writing, the adjustment needs of students in primary schools, more display images as illustrations to attract interest in reading elementary school students, and the students can be more environmentally friendly. The results of the validation test product by 3 (three) experts and four (4) practitioners, validating the product after measurement of the experts, the design model of entrepreneurship education reached $66.94 \%$ in the category of "very high".

Seventh, assessment testing product by experts and practitioners. The results of the product assessment by experts and practitioners are as follows table 2.

Table 2. Results Assessment of experts and practitioners on the product

\begin{tabular}{cll}
\hline No. & \multicolumn{1}{c}{ Corrected components } & \multicolumn{1}{c}{ Criticism and suggestions } \\
\hline 1 & $\begin{array}{l}\text { Principle Needs primary school } \\
\text { age children }\end{array}$ & $\begin{array}{l}\text { Skills learning program should be collated } \\
\text { on the basis of the real financing needs } \\
\text { and can adapt to the needs, the ability of } \\
\text { elementary school students }\end{array}$ \\
\hline 2 & $\begin{array}{l}\text { Principle the cascading material } \\
\text { exposure remains adjust the power } \\
\text { of reading in elementary school } \\
\text { students }\end{array}$ & $\begin{array}{l}\text { The illustration in material exposure more } \\
\text { pictures to motivate students }\end{array}$ \\
\hline 3 & $\begin{array}{l}\text { Principle-centered approach to the } \\
\text { problem }\end{array}$ & $\begin{array}{l}\text { The problem being solved is a problem } \\
\text { faced by the subject (student) }\end{array}$ \\
\hline 4 & $\begin{array}{l}\text { The stages of the development of } \\
\text { entrepreneurship education } \\
\text { activities }\end{array}$ & $\begin{array}{l}\text { a. The stages in the implementation } \\
\text { process skills }\end{array}$ \\
\hline 5 & $\begin{array}{l}\text { This entrepreneurial materials, } \\
\text { adjust to the circumstances of age } \\
\text { readers }\end{array}$ & C. Stages weaving skills \\
\hline
\end{tabular}

Based on table 2 above, it can be seen that the components that must be revised include the principles of elementary school age needs, the principles in the presentation of material must continue to adjust to the reading ability of elementary school students, the principle of a problem-centered approach, the stages of developing entrepreneurship education model activities, and entrepreneurship education teaching materials tailored to the circumstances of the age of the readers.

Eight, revisions to complete the product. The results of the final product revision can be presented as table 3 . 
Desak Made Darmawati, Nadiroh, Arita Marini, Developing Entrepreneurship Education Model...

Table 3. Results of Revised Product by Experts and Practitioners

\begin{tabular}{|c|c|c|c|}
\hline No. & Component & Revision Item & Specification Revision \\
\hline 1 & $\begin{array}{l}\text { In terms of language use } \\
\text { language effectively. }\end{array}$ & $\begin{array}{l}\text { In terms of the choice of } \\
\text { language, this textbook } \\
\text { has been good. }\end{array}$ & $\begin{array}{l}\text { In terms of the language } \\
\text { already repaired suit a } \\
\text { child's age in SD }\end{array}$ \\
\hline 2 & The use of language rules & $\begin{array}{l}\text { The use of language } \\
\text { rules are good enough, } \\
\text { but too high for SD. }\end{array}$ & $\begin{array}{l}\text { It has been fixed by the } \\
\text { rules of elementary } \\
\text { school age children }\end{array}$ \\
\hline 3 & $\begin{array}{l}\text { Motivating and provide } \\
\text { meaningful messages and } \\
\text { information }\end{array}$ & $\begin{array}{l}\text { Pretty good, but it has } \\
\text { motivated when plus the } \\
\text { use of pictures and } \\
\text { illustrations. }\end{array}$ & $\begin{array}{l}\text { Illustrations have been } \\
\text { repaired, to motivate } \\
\text { students to read primary } \\
\text { school children (SD) }\end{array}$ \\
\hline 4 & $\begin{array}{l}\text { The use of language in } \\
\text { primary schools can adapt to } \\
\text { the intellectual development } \\
\text { of students. }\end{array}$ & $\begin{array}{l}\text { Selection of the grammar } \\
\text { and content of the } \\
\text { material is still too high } \\
\text { for elementary students. }\end{array}$ & $\begin{array}{l}\text { Grammar and content of } \\
\text { the material has been } \\
\text { revised to adjust to the } \\
\text { age of elementary school } \\
\text { children }\end{array}$ \\
\hline 5 & $\begin{array}{l}\text { The message can be read } \\
\text { properly }\end{array}$ & $\begin{array}{l}\text { The message conveyed } \\
\text { is good, but still there is } \\
\text { a revision accordance } \\
\text { with age elementary } \\
\text { school students }\end{array}$ & $\begin{array}{l}\text { Message communication } \\
\text { has been revised to adjust } \\
\text { elementary school } \\
\text { children }\end{array}$ \\
\hline 6 & $\begin{array}{l}\text { The use of the term } \\
\text { consistent }\end{array}$ & $\begin{array}{l}\text { The use of the term } \\
\text { consistently been good, } \\
\text { but the power suit a } \\
\text { student in elementary } \\
\text { school reading }\end{array}$ & $\begin{array}{l}\text { The term has been } \\
\text { replaced with a sentence } \\
\text { consistent intention to } \\
\text { focus }\end{array}$ \\
\hline 7 & Exposure of the material & $\begin{array}{l}\text { Already Well, cascading } \\
\text { still adjust the reading } \\
\text { ability of students in } \\
\text { primary }\end{array}$ & $\begin{array}{l}\text { Exposure of the material } \\
\text { is fixed, material } \\
\text { exposure more pictures }\end{array}$ \\
\hline 8 & $\begin{array}{l}\text { Adjust teaching materials } \\
\text { with natural conditions and } \\
\text { the age of its readers }\end{array}$ & $\begin{array}{l}\text { We recommend this } \\
\text { textbook more rendered } \\
\text { images that elementary } \\
\text { school students } \\
\text { interested in reading and } \\
\text { display of images made } \\
\text { as attractive as possible }\end{array}$ & $\begin{array}{l}\text { Textbooks have been } \\
\text { repaired with a lot of give } \\
\text { illustrations than the } \\
\text { material }\end{array}$ \\
\hline
\end{tabular}

Ninth, revisions to main products. Based on input and suggestions from experts and practitioners provide some input as the following table.

Table 4. Revised of Main Product by Experts \& Practitioners

\begin{tabular}{llll}
\hline No. & Corrected components & \multicolumn{1}{c}{ Criticism and suggestions } & Revision \\
\hline 1. & $\begin{array}{l}\text { In terms of language use } \\
\text { language effectively }\end{array}$ & $\begin{array}{l}\text { Sentences are too raw and difficult to } \\
\text { digest by students, especially } \\
\text { elementary school students }\end{array}$ & Repaired \\
\hline 2. & The use of language rules. & $\begin{array}{l}\text { Own right, should be connected to } \\
\text { the needs of primary school children }\end{array}$ & Repaired \\
\hline
\end{tabular}


Desak Made Darmawati, Nadiroh, Arita Marini, Developing Entrepreneurship Education Model...

\begin{tabular}{|c|c|c|c|}
\hline 3. & $\begin{array}{l}\text { Motivating and provide } \\
\text { meaningful messages and } \\
\text { information }\end{array}$ & $\begin{array}{l}\text { Not appropriate to motivate children } \\
\text { in elementary school }\end{array}$ & Repaired \\
\hline 4. & $\begin{array}{l}\text { The use of language in } \\
\text { primary schools can adapt } \\
\text { to the intellectual } \\
\text { development of students. }\end{array}$ & $\begin{array}{l}\text { Adjust with the elementary school } \\
\text { students }\end{array}$ & Repaired \\
\hline 5. & $\begin{array}{l}\text { The message can be read } \\
\text { properly }\end{array}$ & For adults easier to understand & Repaired \\
\hline 6. & $\begin{array}{l}\text { The use of the term } \\
\text { consistent }\end{array}$ & $\begin{array}{l}\text { Said consistently adjust to the power } \\
\text { of reason students }\end{array}$ & Repaired \\
\hline 7. & Exposure of the material & $\begin{array}{l}\text { Good exposure of the material } \\
\text { already, but adapted to the } \\
\text { comprehension ability of elementary } \\
\text { school children. }\end{array}$ & Repaired \\
\hline 8. & $\begin{array}{l}\text { Suggestions for } \\
\text { improvement of teaching } \\
\text { materials }\end{array}$ & $\begin{array}{l}\text { More images which appear to be of } \\
\text { primary school students interested in } \\
\text { reading and display of images made } \\
\text { as attractive as possible }\end{array}$ & Repaired \\
\hline
\end{tabular}

Tenth, dissemination and implementation. In the end step, the researchers disseminate the results research in the form teachers and students textbooks, scientific article to publish in scientific journals, and recommending the implementation of entrepreneurship education model developed to policy makers, particularly the principal of primary schools in enhancing creativity skills of the students through the model of entrepreneurship education that developed.

Improvement of Knowledge, Attitude, and Skills of Elementary School Students through Entrepreneurship Education Model.

Based on descriptive analysis of the ability of grade 5 students as many as 50 students on aspects of knowledge, aspects of attitude, and aspects of skills can be presented as the diagram 1. 


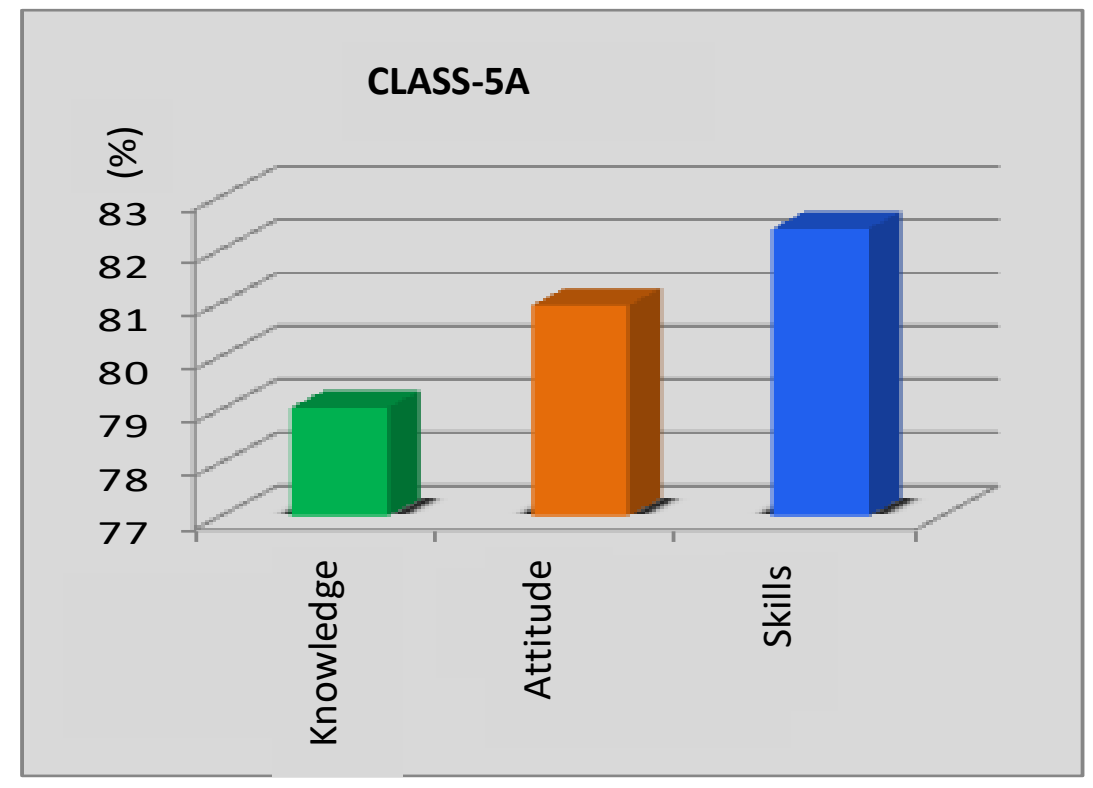

Diagram 1. Assessment Result of 5A class students

From the diagram 1 above, obtained that the aspects of students' entrepreneurship education knowledge are $79.04 \%$, aspects of student attitudes are $80.96 \%$, and aspects of student entrepreneurial skills are $82.40 \%$. This means that the application of the entrepreneurship education model that has been developed has a positive impact on the knowledge, attitudes and skills of 5A grade students at SD Muhammadiyah 5 South Jakarta with a high category.

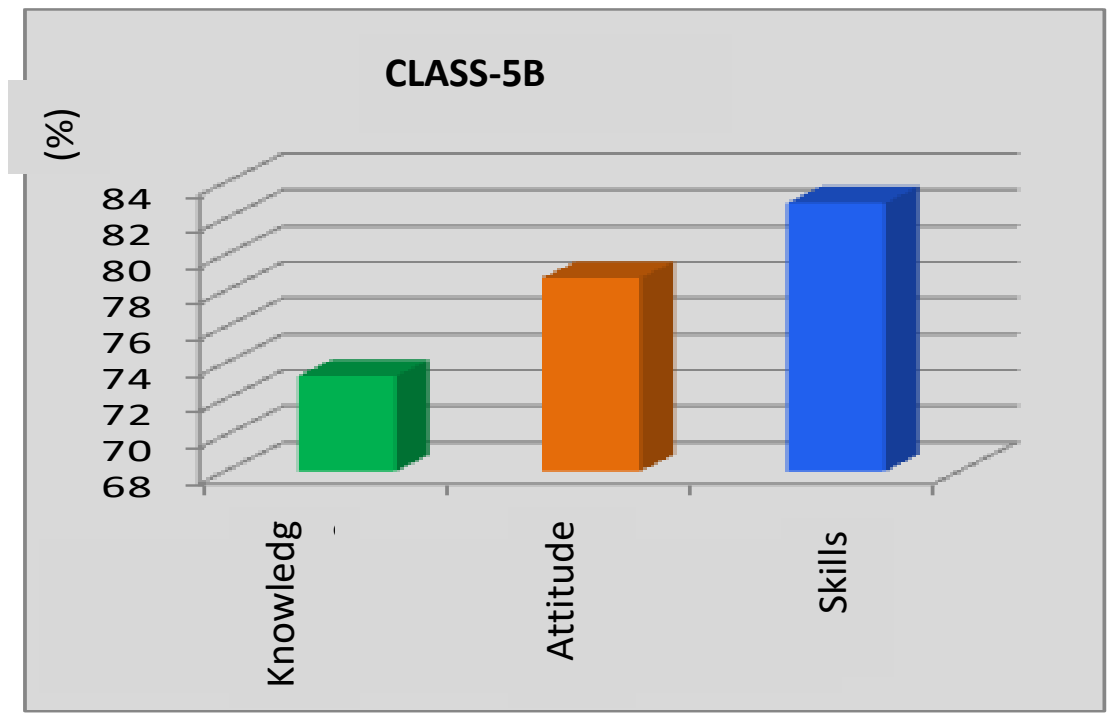

Diagram 2. Assessment Result of 5B class students

From the diagram 2 above, obtained that the aspects of students' entrepreneurship education knowledge are $73.28 \%$, aspects of student attitudes are $78.72 \%$, and aspects of student entrepreneurial skills are $82.88 \%$. This means that the application of the entrepreneurship education model that has been developed has a positive impact on the 
knowledge, attitudes and skills of 5B grade students at SD Muhammadiyah 5 South Jakarta with a high category.

Based on the results of descriptive analysis of the ability of students of grade 5A and 5B of SD Muhammadiyah 5 South Jakarta, the average aspect of students' entrepreneurship education knowledge was $76.16 \%$, aspects of student attitudes were $79.84 \%$, and aspects of student entrepreneurship skills were $82.86 \%$. This means that the application of the entrepreneurship education model that has been developed has a positive impact on the knowledge, attitudes and skills of students in grade 5A and grade 5B at SD Muhammadiyah 5, South Jakarta.

Based on the description of the results of the study above shows that the entrepreneurship education model developed meets valid criteria and is suitable for use, where the results of the assessment of the validator experts and practitioners amounted to $66.94 \%$ with a very high category. This is because the entrepreneurship education model developed is appropriate to the needs and abilities of elementary school students (Huber, Sloof, \& Van Praag, 2014); (Bahmani, Arasti, \& Hosseini, 2018). In addition, the application of entrepreneurship education in elementary schools is also integrated with other subjects (Mulyani, 2011) and is associated with the context of everyday life, so that creative ideas emerge in students (Khayati, 2009). And here the teacher's role is very important in instilling an entrepreneurial spirit in students (Baek, Kang, \& Yi, 2017). In entrepreneurship education, teachers can also provide lessons through skills and creativity that can change the character of students for the better (Aslan, 2010).

The development of entrepreneurship education in elementary schools can be done based on the 2013 curriculum comprehensively through hard skills and soft skills, including (1) introducing entrepreneurship education in elementary schools as social science, (2) deepening the skills material, (3) conducting entrepreneurial practices, (3) integrated entrepreneurship material with relevant local content subject matter, such as: introducing the use of recycled raw materials, economic and cultural benefits in society, and (4) extracurricular activities of weaving skills, school culture or rules that have been made by school (Dewanti., 2017).

The application of the developed entrepreneurship education model can also improve the aspects of knowledge, attitudes and skills of elementary school students, where aspects of student entrepreneurship education knowledge are $76.16 \%$, aspects of student attitudes are $79.84 \%$, and aspects of student entrepreneurship skills are $82,86 \%$. This means that the application of the entrepreneurship education model that has been developed has a positive 
impact on the knowledge, attitudes and skills of students in grade 5A and grade 5B at SD Muhammadiyah 5, South Jakarta. This is in accordance with the results of his research de Lourdes Cárcamo-Solís, del Pilar Arroyo-López, del Carmen Alvarez-Castañón, \& GarcíaLópez, (2017) which revealed that the application of entrepreneurship education can improve students' entrepreneurial skills. And according to Irawan \& Mulyadi (2016), entrepreneurial skills will have a positive influence on business success. In addition, entrepreneurship education can also change students' entrepreneurial attitudes for the better (Kirkley, 2017). Where entrepreneurship education has a positive influence on perceived behavioral control (PBC), subjective norm, and attitude (Wirandana \& Hidayati, 2017).

\section{CONCLUSION}

Based on the description of the results of the research and discussion above, it shows that the entrepreneurship education model developed meets valid criteria and is suitable for use, where the results of the assessment of the validator experts and practitioners amounted to $66.94 \%$ with a very high category. The application of the developed entrepreneurship education model can also improve the aspects of knowledge, attitudes and skills of elementary school students, where aspects of student entrepreneurship education knowledge are $76.16 \%$, aspects of student attitudes are 79.84\%, and aspects of student entrepreneurship skills are 82, $86 \%$. This means that the application of the entrepreneurship education model that has been developed has a positive impact on the knowledge, attitudes and skills of students in grade $5 \mathrm{~A}$ and grade 5B at SD Muhammadiyah 5, South Jakarta. Therefore, this entrepreneurship education model can be an alternative in developing entrepreneurship education in elementary schools.

\section{REFERENCES}

Agustina, D. A. (2017). Model Pembelajaran untuk Mengenalkan Kewirausahaan pada Siswa Sekolah Dasar Kelas Rendah. Bangun Rekaprima: Majalah Ilmiah Pengembangan Rekayasa, Sosial dan Humaniora, 3(2, Oktober), 43-56.

Aslan, S. (2010). The views of primary school 4thand 5thyear students and teachers regarding entrepreneurship. In Procedia - Social and Behavioral Sciences (Vol. 9, pp. 17361740). https://doi.org/10.1016/j.sbspro.2010.12.392.

Azizi, M., \& Mokhtari, N. (2018). Integrated Approach as a Way of Overcoming Entrepreneurship Education Challenges in Elementary Schools in MENA Countries: Evidence from Iran. In Entrepreneurship Education and Research in the Middle East and North Africa (MENA) (pp. 155-168). Springer, Cham.

Baek, M. J., Kang, K. K., \& Yi, B. J. (2017). A Study on the Current status and the Educational Needs of Entrepreneurship Education Program: Focused on Elementary 
and Secondary School Teachers. Journal of the Korea Academia-Industrial cooperation Society, 18(12), 564-574.

Bahmani, N., Arasti, Z., \& Hosseini, S. R. (2018). Entrepreneurship education in elementry schools in order to improve entrepreneurial attitude. Journal of Entrepreneurship Development, 10 (4), 555-573.

Borg, W. R. and M. D. G. (1983). Educational Research: An Introduction, 4th edition. Michigan: Longman Publisher.

de Lourdes Cárcamo-Solís, M., del Pilar Arroyo-López, M., del Carmen Alvarez-Castañón, L., \& García-López, E. (2017). Developing entrepreneurship in primary schools. The Mexican experience of "My first enterprise: Entrepreneurship by playing". Teaching and Teacher Education, 64, 291-304.

Dewanti. (2017). Pengembangan model Kewirausahaan di Sekolah Dasar Kelas Rendah. Jurnal Bangun Rekaprima, 3(1), 80.

Dewi, L., Yani, A., \& Suhardini, A. D. (2015). Model pendidikan karakter dan kewirausahaan berbasis etnopedagogis di sekolah dasar kampung Cikondang. MIMBAR: Jurnal Sosial dan Pembangunan, 31(2), 399-408.

Hassi, A. (2016). Effectiveness of early entrepreneurship education at the primary school level: Evidence from a field research in Morocco. Citizenship, Social and Economics Education, 15(2), 83-103.

Huber, L. R., Sloof, R., \& Van Praag, M. (2014). The effect of early entrepreneurship education: Evidence from a field experiment. European Economic Review, 72, 76-97.

Irawan, A., \& Mulyadi, H. (2016). Pengaruh Keterampilan Wirausaha terhadap Keberhasilan Usaha (Studi Kasus pada Distro Anggota Kreative Independent Clothing Kommunity di Kota Bandung). Journal of Business Management and Entrepreneurship Education, $1(1), 213-223$.

Kirkley, W. W. (2017). Cultivating entrepreneurial behaviour: entrepreneurship education in secondary schools. Asia Pacific Journal of Innovation and Entrepreneurship.

Mulyani, E. (2011). Model pendidikan kewirausahaan di pendidikan dasar dan menengah. Jurnal Ekonomi dan Pendidikan, 8(1).

Putra, H. P., \& Yuriandala, Y. (2010). Studi Pemanfaatan Sampah Plastik Menjadi Produk dan Jasa Kreatif. Jurnal Sains \&Teknologi Lingkungan, 2(1), 21-31. https://doi.org/10.20885/jstl.vol2.iss1.art3.

Putri, R. F. (2018). Pelatihan Pemanfaatan Barang Bekas Menjadi Barang Yang Bernilai Ekonomi. In Amaliah: Jurnal Pengabdian Kepada Masyarakat (Vol. 2, pp. 150-155). https://doi.org/10.32696/ajpkm.v2i1.107.

Robert. (2019). Republika. CO. ID. Manado.

Shakir. (2020). Hasil wawancara pendidikan kewirausahaan.

Siwiyanti, L., \& Uswatun, D. A. (2016). Mengembangkan Pendidikan Kewirausahaan Melalui Pembelajaran IPA di SD. PEDAGOGIK (Jurnal Pendidikan Sekolah Dasar), 4(2), 58-70.

Sukardi, S., Ismail, M., \& Suryanti, N. M. N. (2014). Model Pendidikan Kewirausahaan Berbasis Keterampilan Lokalbagi Anak Putus Sekolah pada Masyarakat Marginal. Jurnal Cakrawala Pendidikan, 33(3). 
Tanan, A. (2010). Antonius Tanan Mendidik "Entrepreneur"". Retrieved February 22, 2010,from https://edukasi.kompas.com/read/2010/02/22/07371843/Antonius.Tanan.Mendidik.qu ot.Entrepreneur.quot.

Usman, et.all. (2010). Pengembangan Pendidikan Kewirausahaan. Jakarta: Pusat Kurikulum Balai Litbang Kementerian Pendidikan Nasional.

Wibowo, A., \& Saptono, A. (2018). Does entrepreneurial leadership impact on creativity and innovation of elementary teachers? Journal of Entrepreneurship Education, 21(2).

Wirandana, E., \& Hidayati, S. (2017). Pengaruh Pendidikan Kewirausahaan Terhadap Niat Berwirausaha. EDUKA: Jurnal Pendidikan, Hukum, dan Bisnis, 2(2).

Yohanna, L. (2018). Urgensity of entrepreneurship education on elementary school education in improving competitiveness. Journal of Education Kahuripan, 1(2), 36-49. 